


\section{Universidade de Brasília}

\section{Faculdade de Educação}

A Compreensão Leitora de Alunos do Ensino Fundamental.

INGRID DE SOUSA ANDRADE

Brasília

2010. 


\section{Universidade de Brasília- UnB \\ Faculdade de Educação}

A Compreensão Leitora de Alunos do Ensino Fundamental

INGRID DE SOUSA ANDRADE

Orientadora: Profa. Dra. Eda Maria de Oliveira Henriques.

Brasília, DF

2010 


\title{
A Compreensão Leitora de Alunos do Ensino Fundamental
}

\author{
Monografia apresentada como requisito para a graduação no \\ curso de Pedagogia.
}

Banca Examinadora:

Prof. . . Dra. Eda Maria de Oliveira Henriques (Orientadora) - UnB

Prof. a . Dra. Vera Aparecida de Lucas Freitas (Membro) - UnB

Prof. ..Dra. Sandra Ferraz de Castillo Dourado Freire (Membro) - UnB

Brasília-DF

2010 
Para Eliel, amor, companheiro e exemplo de alegria.

E minha família, exemplo de união e força. 


\section{AGRADECIMENTOS}

Acredito que as nossas conquistas são fruto não apenas do nosso esforço, mas também do apoio que recebemos ao longo de nossas vidas, vindo de pessoas que cruzam nossos caminhos e marcam nossa história com esperança, força e determinação.

Aos meus pais Rita Maria e Josamir e a minha irmã Lizandra, pelo constante afeto e apoio dedicados para que todo o caminho percorrido durante o curso e também para a construção e término do trabalho final, fosse repleto de paz, tranqüilidade e segurança.

Ao meu namorado e eterno amor da minha vida, Eliel, pelo carinho e dedicação a mim a todo instante. Sem suas idéias sempre muito bem fundamentadas e precisas, não conseguiria seguir de forma coerente até aqui. Pessoa linda, esforçada, inteligente, dedicada e amorosa, são sinônimos de Eliel. Compartilhar este momento, além de sonhos e metas com este belo homem só faz aumentar a minha paixão e o meu amor.

Á professora Vera Aparecida, por me ajudar em um momento difícil durante o curso de Pedagogia e me fazer acreditar que com esforço e determinação é possível seguir adiante de cabeça erguida.

Á minha orientadora, professora Eda Henriques pelo estímulo constante. Com sua vibração, disponibilidade de tempo e jeito empolgado de ser, foi possível trilhar um caminho certo para a construção deste trabalho. 
Aos professores e funcionários da Escola 49 de Taguatinga Norte, pela simpatia que permitiu um bom trabalho na instituição.

A todos da Faculdade de Educação, como os colegas de turma e demais professores que, mesmo indiretamente, se fizeram presentes e atuantes durante o curso. Por meio deles pude desenvolver uma base sólida e segura como pedagoga.

A todos vocês, meu muito obrigada. 
“A educação sozinha não transforma a sociedade, sem ela tampouco a sociedade muda”. (Paulo freire) 


\section{RESUMO}

Este trabalho monográfico apresenta estudo acerca da compreensão leitora de alunos do ensino fundamental, por meio de observações e intervenções em aulas na rede pública de ensino a partir do trabalho realizado nos projetos três e quatro na Faculdade de Educação. $\mathrm{O}$ primeiro, cujo tema construído foi "Alfabetização e linguagem: Práticas de leitura" serviu como base para trabalhar textos e interpretações com os alunos. O segundo projeto, "Letramento e formação de professores", permitiu de forma mais significativa a construção deste trabalho tendo em vista a descrição das aulas administradas na Escola Classe 49 localizada em Taguatinga Norte. A leitura como forma de aproximação entre a estagiária e as crianças, é o ponto crucial deste trabalho que visa à importância da interação em sala de aula como caminho para a construção conjunta do conhecimento. Com este estudo, espera-se promover a reflexão de que a leitura permeia a vida social e acadêmica dos alunos, sendo papel urgente dos pais e educadores contribuir para o processo de letramento das crianças, de maneira a criar as possibilidades para o acesso e interesse das mesmas por leituras de textos diversos que circulam na sociedade, com a proposta indispensável do uso de práticas pedagógicas que venham a facilitar a compreensão leitora dos alunos.

Palavras-chave: Letramento; Leitura; Projetos; Ensino Fundamental; Compreensão Leitora. 


\begin{abstract}
This monograph presents a study on the reading comprehension of elementary school students through classroom observations and interventions in public schools from the work carried out at the third and fourth projects at the Faculty of Education. The first, built the theme was "Literacy and language: Practice reading" served as a base to work from texts and interpretations of students. The second project, "Literacy and Teacher Education", allowed a more meaningful way of this construction work taking view a description of the classes given in Class 49 School located in North Taguatinga. Reading as a form of reconciliation between trainee and children, is the crux of this work which aims at the importance of interaction in the classroom as a way for the joint construction of knowledge. This study is expected to promote thought that reading permeates social life and academic students, and urgent role of parents and educators contribute to the literacy of children in order to create opportunities for access and interest by the same readings of various texts that circulate in society, with the proposed essential use of pedagogical practices that will facilitate the reading comprehension of students.
\end{abstract}

Key-Words: Literacy; Reading; Projects; Elementary School; Understanding Reader. 


\section{SUMÁRIO}

1 MEMORIAL

2 INTRODUÇÃO

3 APRESENTANDO A ESCOLA

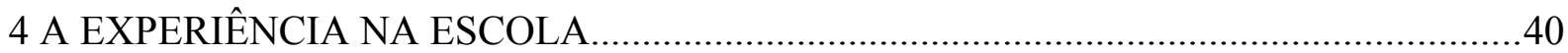

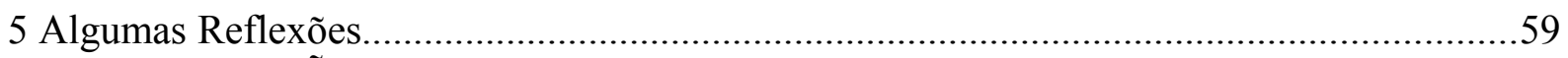

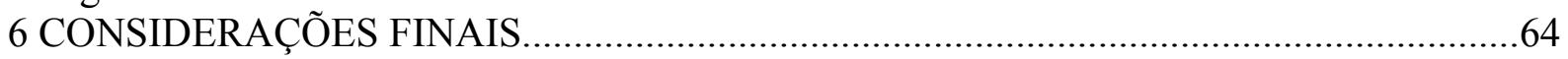

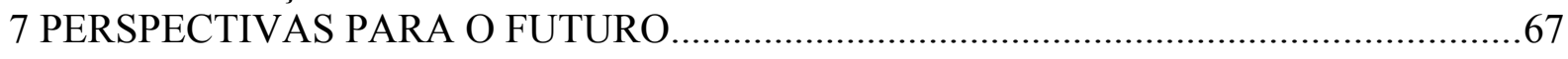




\section{MEMORIAL}

Este trabalho monográfico tem como proposta relatar a experiência vivida ao longo dos projetos três e quatro junto às professoras Vera Aparecida e Stella Maris, ambas da Faculdade de Educação, que permitiram vivenciar a questão da compreensão leitora numa turma do $2^{\mathrm{a}}$ ano do ensino fundamental na escola classe 49 . Os temas trabalhados durante os projetos três e quatro por estas docentes se entrelaçaram de tal maneira até que fosse possível chegar à questão da importância das práticas de leitura e a compreensão leitora e seu desenvolvimento junto a alunos do ensino fundamental.

Neste memorial procuro fazer um inventário da minha trajetória de formação até chegar à Universidade de Brasília, e os caminhos que me levaram a eleger a compreensão leitora como tema do meu trabalho de conclusão de curso.

São objetivos da escola e das famílias em geral proporcionar às crianças o acesso ao conhecimento e a formação de indivíduos críticos, comprometidos consigo mesmos e com a sociedade, capazes de intervir modificando a realidade, auto motivados e aptos a buscar o aprendizado e o aperfeiçoamento contínuos, o que passa pela formação de leitores competentes.

É fato sabido que várias gerações têm demonstrado não apenas o desinteresse pela leitura, mas também a incapacidade de fazê-la coerentemente, compreendendo um texto a partir da sua interpretação, o que inegavelmente limita o indivíduo em suas possibilidades de acesso ao conhecimento culturalmente construído. 
A compreensão leitora pode ter como desdobramento o desenvolvimento do processo cognitivo do aluno e levando-o a melhorar sua concentração, a prestar atenção em detalhes que uma leitura descompromissada e sem direcionamento perde. Nós, como professores, pretendemos levar os alunos a se tornarem leitores expressivos quando se trata do processo de interação e relação significativa do trabalho com textos.

Mesmo antes de entrar em uma escola, a colaboração dos meus pais foi fundamental para que eu começasse a ouvir histórias e, a partir delas, construir meus próprios passos no que se refere á leitura e á escrita.

É tarefa urgente dos pais e da escola, em todos os níveis, buscar maneiras de estimular, mais do que a capacidade de ler, o sentido que esta leitura pode trazer. Apenas proporcionando aos sujeitos leitores o prazer da leitura poderemos construir as competências necessárias para sua apreensão e produção.

\subsection{A trajetória escolar}

A trajetória escolar faz parte da vida de muita gente, é um momento único, prazeroso, angustiante, fraterno e especial. São vários os instantes que me marcaram e que prevalecem em minha memória até hoje, são coisas que acredito nunca esquecer. Espero sempre recordar com entusiasmo e saudade tudo que vivi nas escolas que estudei e, principalmente, poder compartilhar através deste trabalho, experiências e histórias de outras pessoas que também marcaram minha vida na escola. A escrita de toda uma vida acadêmica é instigante e desperta tudo ou boa parte do que foi uma trajetória na vida escolar, seja para relembrar bons momentos, seja para jamais esquecer o que já é para mim, o inesquecível: o exercício da memória educativa. 
O referido estudo para a construção deste trabalho teve sua fundamentação a partir de vivências e práticas ao longo de uma vida acadêmica. E é a partir das diversas opções que desencadeiam em boas escolhas que surgem grandes oportunidades ao longo da vida, sendo que optar pela área educacional foi uma excelente aposta.

Apesar da pouca idade, lembro-me das séries iniciais que fiz, era rodeada de amizades, gostava dos professores e outros funcionários da escola, procurava mais diversão a estudo, mas sempre com a responsabilidade de fazer trabalhos, deveres de casa. Enfim, desde criança, comecei um processo de aprender a me organizar e passar essa aprendizagem para aqueles que estavam próximos a mim. Adorava a escola onde estudava na época do jardim até chegar a $1^{\mathrm{o}}$ série do ensino fundamental, lembro que a professora ainda muito jovem e inexperiente em sala de aula acabava fazendo as vontades da turma. Na escola onde estudava, adorava brincar com massas de modelar, tinta guache e desenhar. Era uma forma de interação que havia em sala de aula para que os colegas de classe pudessem ter liberdade, ter um bom ano letivo, tanto entre os colegas, como entre os professores. Nos intervalos das aulas, fazíamos piquenique, lanches em grupo, brincadeiras educativas. Tudo era muito bom apesar de só começar a gostar da escola um tempo depois, isto porque como quase toda criança, tive receio de ficar sem a presença da mãe por perto e, passar a conviver com colegas e professores em um ambiente pouco conhecido, gera ansiedade e medo.

Acredito que durante o ensino fundamental comecei a ser mais exigente em relação à escola, foi um tempo de total absorção dos conteúdos que me foram passados em sala de aula, fiz poucas amizades por motivos de troca de colégio e dificuldade de adaptação. Estudiosa e dedicada, obtive as melhores notas da turma e o reconhecimento dos professores pela minha atuação nas matérias. 
Recebia elogios, ouvia palavras de motivação dos educadores, mas não a plena satisfação de estar bem por completo, pois me sentia sozinha restrita a poucas amizades, motivos que me deixavam desanimada, porém com a certeza de que aquele momento foi importante para que houvesse uma fase de amadurecimento na vida. Foi um período marcado de grande aprendizado, tive bons professores apesar das tamanhas críticas que a escola pública sofre, pois mesmo com as dificuldades ainda há grandes educadores que prezam por fazer a diferença nas aulas.

Dentre estes brilhantes e pouco valorizados profissionais, eu gostei muito de dois professores no ensino fundamental, um que lecionava aulas de História, chamado Aldemir e outra professora que admirei muito chamada Lúcia, que lecionava aulas de Português. Foi por meio dela que comecei a gostar de ler e procurar sempre por grandes obras literárias. Seus métodos eram desenvolvidos por meio da construção de fichas literárias feitas pelos alunos, formação de grupos de discussão para o enriquecimento literário, escolha de alunos para elaboração de perguntas com a finalidade de aferir o conhecimento adquirido por meio da leitura. Infelizmente tive a triste notícia que Lúcia faleceu em decorrência de um acidente de carro, ela era jovem demais e promissora demais na carreira que seguia, para morrer e deixar de educar muitos que, viriam a conhecê-la, e ter o mesmo aprendizado que obtive através dela. Mas a vida é assim, nos pregam peças que jamais podemos imaginar que aconteça um dia.

O ensino médio considero o melhor e o mais saudoso de todos os momentos que tenho na memória quando se fala em escola, pois fiz amizades verdadeiras que duram até hoje, as responsabilidades começaram a ser mais freqüentes juntamente com as cobranças de se passar em um vestibular e seguir uma carreira. 
Lidar com a separação dos amigos também é um fator preponderante neste período de mudanças para os jovens que precisam seguir suas vidas, pois cada um acaba trilhando caminhos diferentes depois do ensino médio. Enfim, etapas que acontecem na vida e que devemos sempre encará-las de forma natural e com maturidade. Nesse período, conheci pessoas maravilhosas que fizeram diferença na minha vida, lembro que formamos um grupo logo no primeiro dia de aula e permanecemos com este mesmo grupo até o fim do ensino médio. Tivemos momentos de muita descontração e de concentração nas aulas.

No ensino médio também tive bons professores, uma boa base teórica, gostei muito do ambiente no qual estava inserida e me sentia bem com a companhia de amigos e funcionários da escola, pois a instituição de ensino desenvolvia um projeto em que os alunos eram instigados à prática da leitura de determinadas obras literárias, que porventura seriam utilizadas no Programa de Avaliação Seriada - PAS/UnB. As atividades realizadas ultrapassavam os limites da disciplina de Língua Portuguesa por buscarem interdisciplinaridade com outras matérias, com a realização de peças teatrais abertas ao público em geral e que mobilizavam toda a escola para tal finalidade.

O cursinho pré-vestibular também fez parte da minha vida depois do ensino médio, foi através do mesmo que comecei a ter uma noção maior do que era a UNB, de como conseguiria ingressar nessa Universidade. Foi com muito esforço e força de vontade, que consegui chegar até a Pedagogia. $\mathrm{O}$ curso oferece uma grande abrangência de informações e apesar de gostar da área educacional, tenho plena consciência que muitas mudanças deverão ser promovidas por nós educadores e também toda a sociedade para que a educação brasileira seja fortalecida e tenha como meta instigar crianças, jovens e adultos a ler, a escrever, a raciocinar e ter o pensamento crítico necessário para expressar suas próprias opiniões. 
Tais mudanças que devemos adotar estão relacionadas às práticas pedagógicas que deverão observar principalmente o meio social em que o aluno está inserido, atentar para as experiências que o aluno traz para a sala de aula, de maneira a contribuir pelo despertar dos interesses da criança no âmbito acadêmico. De outro lado, a participação dos pais e da própria sociedade no acompanhamento das atividades desenvolvidas pelas instituições de ensino é de extrema relevância para a promoção do interesse dos alunos nas práticas acadêmicas, pois este estímulo não deve ser encarado apenas como um papel a ser desempenhado pelo educador, mas é dever de toda a comunidade escolar.

O curso de Pedagogia da UnB me trouxe uma enorme oportunidade de enxergar os desafios e metas que serão vistos em sala de aula no que diz respeito ao comportamento dos alunos, as práticas pedagógicas adotadas pelo professor, ao trabalho da equipe escolar e outros fatores indispensáveis para que haja um bom funcionamento de toda a instituição.

\subsection{O Curso de Pedagogia}

A seguir gostaria de destacar o papel do curso de Pedagogia em minha vida e os caminhos que me levaram até este excelente curso, repleto de qualidades, mas também defeitos, que poderão ser superados com a garra que todo educador deve possuir para propor mudanças e melhorias para os nossos alunos do ensino fundamental.

Desde muito cedo, ainda na fase de socialização na escola, aprendi com professores e colegas a importância de se aprender e principalmente de ensinar o outro por meio da prática. A paixão pelo ato de ensinar sempre se fez presente em minha trajetória enquanto estudante e continuará viva agora como professora. 
Os caminhos que me levaram até o curso de Pedagogia foram traçados a cada dia de maneira sutil, mas com a certeza de sucesso na profissão pelo tamanho interesse e valorização da área educacional concretizados ao longo dos anos na escola. A Pedagogia é um campo de conhecimento apaixonante por não se restringir somente a sala de aula, mas por permitir que os futuros pedagogos consigam atuar além da escola, conquistar espaço em empresas, ONGs, hospitais e outros, objetivando uma educação de qualidade e de continuidade.

O aperfeiçoamento de diversos conhecimentos acerca da Pedagogia como estudante ao longo do curso, agregou gigantesco valor no que diz respeito ao futuro que se reserva no próprio mercado de trabalho. Isto se verifica quando surgem oportunidades de aplicação da aprendizagem obtida na prática. $\mathrm{O}$ curso oferece subsídios que venham a somar com os valores do professor e sua capacidade de transmitir e se relacionar com os alunos acerca do conteúdo a ser administrado em sala de aula.

Contudo, existem muitas abordagens possíveis para propiciar o ato educativo. Por meio do estudo destas abordagens tornou-se possível conceber a idéia de que é necessário repensar os métodos tradicionais, aprender com as questões trazidas pelo construtivismo o qual se preocupa com a construção do conhecimento do aluno, levando em consideração as estruturas cognitivas e o meio histórico-social, além de abrir espaço para o aluno interagir com o meio, resolvendo problemas. Na intenção de transmitir informações e transformá-las em conhecimento, um professor pode optar por diversas maneiras de comunicação com seus alunos. Acredito que estabelecer o diálogo e ter como ponto de partida as próprias experiências da criança como sujeito histórico, é uma forma de melhor trabalhar conteúdos e meios para se chegar a um patamar mais elevado, seja no âmbito da leitura, seja no âmbito de qualquer outra temática. 
A Pedagogia traz importantes balizadores para as ações e os instrumentos didáticos que devem ser utilizados para qualquer nível de educação. A escolha por lecionar está intimamente ligada ao que se deve discutir em sala de aula de maneira a relacionar os conteúdos aplicados com o cotidiano dos alunos. É justamente nesta parte que o letramento como prática social precisa ser evidenciado sempre com as nossas crianças do Ensino Fundamental. Nos dias atuais o lema é de que onde houver uma prática educativa, se instala uma ação pedagógica. O processo de ensino-aprendizagem é vivenciado não somente dentro da escola, mas é uma ação que acontece em todo e qualquer setor da sociedade, que se caracteriza como a sociedade do conhecimento, pois a educação formal e a não formal caminham paralelamente e torna a educação o principal instrumento contra a desigualdade social.

\subsection{Professores e disciplinas}

Os professores e as disciplinas cursadas durante o curso de Pedagogia também serviram como base pela opção da área da leitura. Dentre estes, destaco processo de alfabetização com a educadora Norma Lúcia. Esta disciplina abriu caminhos para se perceber a tamanha riqueza de potencialidades que devemos assumir para alfabetizar os alunos. Emília Ferreiro, principal autora vista durante o semestre, contribuiu para as leituras acerca do método da alfabetização a partir da psicogênese da língua oral e escrita e as diversas fases de seu desenvolvimento que devem ser trabalhadas pelos professores em sala de aula, como a pré - silábica, silábica, silábica - alfabética e alfabética.

Didática fundamental como outra disciplina, veio somar com os conhecimentos já obtidos em relação a como ser professor e planejar aulas criativas e dinâmicas. Por meio da disciplina administrada pela professora Aparecida, foi possível construir meios eficazes de ação educativa como a idéia de que o professor precisa 
desenvolver maneiras de envolver seus alunos na questão ensino-aprendizagem, a partir do conhecimento da matéria, estímulo à atenção, linguagem didática, concretização das idéias e observação do aluno. A aula expositiva pode ser enriquecedora e dinâmica desde que o professor conheça bem o conteúdo, consiga prender a atenção dos alunos, utilize a linguagem didática com todos os seus recursos, procure tornar as idéias concretas e, o mais importante, certificar-se de que os alunos estão aprendendo realmente.

Outra experiência que destaco como primordial para qualquer profissional da educação é vivenciar durante a faculdade, as dificuldades que se tem em sala de aula quando nos deparamos com alunos portadores de necessidades educacionais especiais. $\mathrm{E}$ foi por meio deste processo de descobertas e maiores esclarecimentos acerca das deficiências e de como lidar com possíveis situações em sala de aula, que tive o enorme prazer de ser apresentada ao professor Bianor, um educador exemplar que apesar das suas limitações físicas por conta de uma paralisia cerebral, soube conviver e passar para os alunos do curso de Pedagogia a lição de que todos nós somos capazes de acreditar naquilo que possamos fazer de melhor para a sociedade.

O professor José Vieira, responsável pela disciplina Avaliação das Organizações Educativas, foi uma figura de extrema importância em um semestre que considerei tumultuado e pouco promissor por conta de paralisações de professores, funcionários e outros que prejudicaram o andamento das aulas na UNB. Por meio desta disciplina que visa à avaliação dos sistemas externos às escolas e universidades, pude aprender por meio de provas, seminários e ensaio, a importância que se tem uma Prova Brasil, o Saeb (Sistema de Avaliação da Educação Básica), o Enem (Exame Nacional do Ensino Médio), o Pas (Programa de Avaliação Seriada) e o Siade (Sistema de Avaliação do Desempenho das Instituições Educacionais do Sistema de Ensino do Distrito Federal) no que 
se refere ao que precisa ser melhorado nas instituições brasileiras a partir de dados que refletem a realidade de nossas escolas.

A riqueza das aulas expositivas e as diversas discussões em sala de aula que, desencadearam boas soluções para diversos problemas encontrados nas pesquisas de campo, foram primordiais para se ter em mente o que precisa ser feito para gerar melhorias e ganhos numa determinada escola ou faculdade. O que fica é que a qualidade não se conserva, mas se alcança. E para que de fato haja esta tão almejada qualidade no interior da escola, torna-se imprescindível a socialização de reflexões e experiências dos envolvidos no processo do ato de planejar, a partir da diversidade que se tem dentro de uma organização escolar.

Outro marco durante o curso foi ter a chance de participar de um projeto de extensão muito importante para aqueles que querem ver na prática, as diferentes realidades do nosso Brasil. Isto porque o Projeto Rondon visa discutir a integração social, ponto primordial do projeto, que está intimamente relacionada à preocupação com a cidadania da população brasileira e com os rumos que nossa sociedade está seguindo. A realidade muitas vezes desconhecida e mascarada impedem uma formação universitária adequada e eficiente de acordo com as verdadeiras necessidades do nosso vasto país.

A oportunidade de discutir o desenvolvimento sustentável, a gestão pública e a cidadania com os agentes da comunidade local permitiram a percepção do que é realizado em cada município e a análise de suas conseqüências para o panorama geral do Brasil. Além disso, sugerimos uma construção conjunta de um conhecimento que gerará frutos positivos também para a comunidade escolhida a partir de necessidades autênticas que refletem a realidade atual. Por meio destas questões que o projeto Rondon procura resgatar nos jovens 
estudantes de graduação, a questão da cidadania, vindo a contribuir para a minha formação de maneira significativa.

Por meio da viagem que fiz junto a uma equipe composta por professores e alunos concluintes dos mais diversos cursos, pude obter como aprendizado a importância que se dá ao que nos propomos a oferecer. As oficinas e propostas de palestras para uma comunidade pobre de Minas Gerais, mais apropriadamente da cidade de Comercinho do interior de Minas, foram aperfeiçoadas ao longo de um semestre e postas em prática durante quinze dias pelo sertão mineiro. Com as minhas oficinas "Mestre não é quem sempre ensina, mas quem de repente aprende" e "Coleta Seletiva e a Pedagogia dos Três Rs, pude ter um contato maior com professores, pais e alunos nesta cidade que tão bem nos acolheu e que merece ter dias melhores por conta de problemas sociais que muitos dos nossos governantes poderão se propor a resolver.

A primeira oficina teve o objetivo de mostrar a pais e educadores a importância do papel de ser professor, um profissional que possui muitas potencialidades de interação com alunos, mas que geralmente não se dá conta dessa capacidade. Através de uma boa exploração das personalidades individuais e em grupo, o êxito ensino-aprendizagem foi melhor trabalhado e adaptado na região.

Já a segunda oficina teve como principal meta orientar os agentes municipais, lideranças comunitárias e comunidade quanto à coleta seletiva e reciclagem, e capacitá-los a repassar essa necessidade à população por métodos lúdicos. Capacitar professores a disseminar nas escolas as técnicas de construção de instrumentos musicais a partir do material reciclado. Estas propostas foram bem aceitas pela comunidade e espera-se que tudo o que foi repassado e assimilado pelas pessoas da região, seja proveitoso no que se 
refere ao trabalho cotidiano de jovens e adultos da cidade de Comercinho situada em Minas Gerais.

Enfim, professores marcantes e disciplinas fascinantes, além de projetos como os que fiz desde o começo do curso voltados para a questão do letramento, foram processos significativos que estarão para sempre em minha memória. Agora como educadora, pretendo aplicar todo o conhecimento e a experiência que tive na faculdade, em sala de aula.

\section{$1.4 \quad$ Autores e teorias}

Os autores estudados durante o curso de Pedagogia também fazem parte deste memorial por terem marcado o estudo para cada disciplina. Vygotsky foi o que mais chamou atenção por ser um importante pensador da área do desenvolvimento intelectual das crianças em função das interações sociais e condições de vida destas.

É justamente neste ponto do interagir com alunos em sala de aula, que priorizo o estudo da teoria Vygotskyana e a possibilidade de maior conhecimento sobre o que as crianças se interessam e no que elas podem avançar no que diz respeito ao processo de ensino-aprendizagem. Além de Vygotsky, admiro Paulo Freire e de como é importante trabalhar com este autor quando nos referimos à educação de jovens e adultos, outra rica experiência que tive durante o curso de Pedagogia. Por meio das rodas de conversa mediadas durante os encontros com os alunos da turma que trabalhei, e das leituras levadas para a sala de aula pelos próprios estudantes, como as revistas, jornais e livros literários e também do interesse do professor em saber mais da vida cotidiana dos seus alunos, aprendi o quanto podemos, como educadores, fazer a diferença no processo de ensino-aprendizagem do aluno.

Foi bonito presenciar jovens adultos e idosos aprendendo a ler e escrever, aprendendo os direitos básicos de exercer sua cidadania. Foi gratificante perceber nos olhos 
de cada aluno, a motivação para aprender sempre mais e com a garra de um menino que entrou agora na escola. Sem dúvida, estas cenas se tornarão inesquecíveis pelo contexto histórico destas pessoas que, apesar da idade, do trabalho e do cansaço do dia a dia se propuseram a voltar para uma sala de aula e aprender o que elas não puderam por conta de uma vida difícil desde a infância.

Enfim, aprender a ler e escrever e também fazer uso da leitura e da escrita, transformam o individuo, levam-no a outro estado ou condição sob vários aspectos: social, cultural, cognitivo, lingüístico, entre outros.

No entanto, só o fato de ser alfabetizada não garante que a pessoa seja letrada, e somente o fato de viverem em uma sociedade letrada não garante a todas as pessoas formas iguais de participação na cultura escrita.

Por este motivo, que o letramento, como uma prática social, vai além da alfabetização. Autores como Kleiman e Magda Soares, vêm sistematizar a questão de acompanhar as mudanças promovidas pela nossa sociedade e a contribuição destas mudanças no que diz respeito à importância da leitura e do letramento no dia a dia.

As questões relacionadas às contribuições conceituais dos autores aqui citados serão mais detalhadas ao longo do trabalho.

\subsection{Projetos três e quatro}

O meu interesse imediato pela área da leitura aconteceu ainda no $3^{\circ}$ semestre do curso. A questão de como interagir com as crianças no processo de ensinoaprendizagem da leitura começou a partir da seguinte indagação: como trabalhar práticas de leitura visando à compreensão leitora em crianças do ensino fundamental? 
Neste tempo, estava completamente desacreditada quanto a algumas disciplinas e professores, o que me levou a pensar em desistir da Pedagogia e partir para outra área. Isto porque o cansaço que sofri desde o primeiro dia de aula na UNB foi se tornando intenso e como ainda era caloura na Universidade, não sabia como lidar com esta situação.

Porém, apareceu uma professora muito querida que me ajudou a perceber a tamanha facilidade que tenho em trabalhar com a leitura com crianças do ensino fundamental e de como possuía criatividade e interesse em aplicar o que aprendi ao longo de três semestres na Faculdade de Educação. Professora Vera Aparecida, profissional experiente e atuante na área de língua materna, tornou-se uma referência significativa e valiosa para a minha formação pelo importante auxílio no projeto três cujo tema foi “Alfabetização e linguagem: Práticas de leitura".

A pesquisa proposta pelo projeto voltou-se para as questões de alfabetização e letramento. Por meio da interação entre a pesquisadora e dois alunos da rede pública de ensino, foi possível perceber como está o desenvolvimento da compreensão leitora dos alunos de $5^{\circ}$ e $6^{\circ}$ ano do ensino fundamental. Para isso, a pesquisa teve como ponto de partida, a leitura de textos que agradavam aos alunos e, a partir de tal prática, a ampliação do rol de textos, o trabalho de fazer comparações, reflexões e análises dos diversos gêneros textuais que circulam na sociedade. Por meio deste processo de vivência e reflexão do aluno com a leitura, tornou-se possível apontar os benefícios que esta prática traz.

Os participantes desta pesquisa foram selecionados a partir da sua realidade social. O critério utilizado foi o de selecionar apenas um sujeito, estudante de escola pública, para observação de sua compreensão leitora a partir de textos contidos em um livro didático. Porém, por força maior, o estudante não pôde continuar a participar da pesquisa, realizando 
apenas dois encontros com a pesquisadora. Para a continuidade do trabalho, selecionou-se outro sujeito, também estudante da rede pública de ensino, com a mesma finalidade de se trabalhar a leitura de textos fora do contexto escolar.

O trabalho desenvolvido foi uma pesquisa de campo de abordagem qualitativa e contou com a participação da pesquisadora e dois alunos da rede pública de ensino. A temática, práticas de leitura, foi evidenciada com o objetivo de se fazer entender a capacidade de compreensão leitora dos sujeitos participantes desta pesquisa. Para isso, o processo pelo qual as crianças passaram ao longo dos encontros, foi de grande valia para que pudessem aprimorar a leitura e desenvolver atividades voltadas para dentro e fora do contexto escolar.

O projeto quatro, outra significativa possibilidade de vivenciar a sala de aula, cujo tema foi "Letramento e formação de professores", foi de extrema importância e necessidade, por ter sido um momento de reflexão acerca das minhas próprias metas e maneiras de pensar como atuar como professor- educador numa escola.

A orientadora Stella Maris, experiente na área de etnografia da sala de aula, contribuiu para que o projeto quatro fosse concluído com êxito trazendo as possibilidades para a construção deste trabalho monográfico. Foi nesta fase, que o enriquecimento como pedagoga se tornou mais intenso e maduro no que diz respeito às práticas de ensino adotadas, por me permitir vivenciar o cotidiano e a dinâmica da Escola Classe 49 e assim intervir no processo de desenvolvimento da compreensão leitora das crianças que lá estudam.

Essas marcas que apresentei, são inesquecíveis e altamente importantes na vida de qualquer pessoa que tenha sentido e vivido o que é estar numa escola, ser bem acolhido nela, desenvolver processos importantes de aprendizagem em sala de aula e conviver 
com amigos e profíssionais da educação por alguns anos que, refletem sempre boas experiências de extrema importância para uma vida.

Durante todo o processo de aprendizagem que passei até hoje, aprendi o quanto a presença de um educador é primordial para que possamos dar os primeiros passos em busca de novas conquistas e se realizar ao longo de uma vida acadêmica. Uma frase que admiro de Guimarães Rosa, simplesmente resume o meu memorial educativo: "Mestre não é quem sempre ensina, mas quem de repente aprende". 


\section{INTRODUÇÃ̃O}

Como foi assinalado no início do memorial, esse trabalho se refere ao relato circunstanciado e discutido da experiência vivida ao longo da realização do projeto 4 e que consistiu na realização de uma proposta de prática docente com o objetivo de inserir os alunos nas práticas de leitura, evidenciando a questão da importância destas práticas no desenvolvimento da compreensão leitora.

$\mathrm{O}$ ato de ler é um processo abrangente e complexo, pois se trata de compreender o mundo a partir de uma característica particular ao homem: sua capacidade de interação com o outro através das palavras, que por sua vez estão sempre submetidas a um contexto. A leitura no seu sentido geral amplia nossos horizontes e nos transporta ao mundo da imaginação, sem contar os inúmeros conhecimentos que acabamos adquirindo por meio de universos desconhecidos que mergulhamos.

A partir da importância da leitura em nossas vidas podemos destacá-la como primordial para a construção do conhecimento e também para a construção da autonomia das crianças de forma a aprenderem a ler não somente identificando palavras, mas compreendendo a diversidade dos seus sentidos e as maneiras de interpretação e relação entre elas e com o mundo que nos rodeia.

Por meio deste processo de vivência e reflexão do aluno com a leitura, espera-se apontar os benefícios que esta prática traz. Para isso, Considera-se que o gosto pela leitura se constrói através de um longo processo e que é fundamental para o desenvolvimento 
de potencialidades. É necessário dedicar-se e ter a consciência de que é indispensável propiciar caminhos que levam as crianças a se interessarem pelo hábito da leitura.

Torna-se imprescindível, criar no ambiente pedagógico um clima favorável à leitura, marcado por interações com diálogos entre alunos e professores. Interações que vão permitir muitas leituras de um mesmo texto, por sujeitos que têm histórias, competências, interesses, valores e crenças diferentes. Ao professor cabe reconstruir com seus alunos a trajetória interpretativa de cada um, buscando compreender a construção de cada sentido apontado.

No entanto, para que haja tal realização, os caminhos a serem percorridos não ocorrem de forma imediata, mas são fruto de trabalhos significativos como o que se desenvolveu na Escola Classe 49, com a parceria e troca de experiências entre os alunos e os demais profissionais que compõem a instituição.

Com esta convicção de que as práticas de leitura precisam ser mais bem trabalhadas em sala de aula pelos professores, que este trabalho vem sistematizar a experiência de estágio numa turma do $2^{\mathrm{a}}$ ano do ensino fundamental da rede pública de ensino no que se refere a práticas pedagógicas relacionadas ao desenvolvimento da compreensão leitora.

A partir das observações e intervenções em sala de aula foi possível construir o projeto quatro e também este trabalho que vem apresentar o relato analisado e refletido da experiência na Escola Classe 49, bem como seus reflexos tanto para o estágio quanto para a instituição.

Assim, este trabalho terá na sua composição as seguintes partes: 
$\mathrm{Na}$ primeira parte, descrevemos a Escola Classe 49, falaremos sobre a escolha da escola, seus aspectos físicos, administrativos e financeiros, os projetos anuais que a instituição promove com a proposta de incentivo a leitura e a participação de toda a comunidade escolar. Há também a descrição dos primeiros contatos feitos na instituição, de maneira a compreender as propostas de atividades a serem elaboradas em relação à prática da leitura ao longo do estágio.

Em seguida, abordaremos as observações e algumas das atividades propostas durante o estágio na Escola Classe 49 no que diz respeito às práticas de leitura no desenvolvimento da compreensão leitora dos alunos do $2^{\mathrm{a}}$ ano do ensino fundamental. Neste espaço também apresentamos a abordagem teórica, estabelecendo um diálogo das mesmas com as práticas desenvolvidas ao longo do trabalho.

Na terceira parte, são apresentadas algumas reflexões acerca das práticas de leitura desenvolvidas junto à turma observada do $2^{\mathrm{a}}$ ano do ensino fundamental e suas conseqüências para o desenvolvimento da compreensão leitora.

Por fim, nas considerações finais, retomando o que percorremos ao longo do trabalho, traremos os comentários conclusivos. 


\section{APRESENTANDO A ESCOLA}

A atividade de estágio é um fator significativo na formação do aluno por proporcionar a interação com a realidade da profissão e a complementação do aprendizado acadêmico. Torna-se primordial que a escolha da escola seja de inteira responsabilidade do estagiário, para que a relação entre ele e o professor supervisor de turma, seja satisfatória no sentido de contribuir para o caminhar de um trabalho a ser feito em equipe.

A Escola Classe 49, localizada em Taguatinga Norte, foi selecionada pela praticidade de acesso a instituição, pela disponibilidade de horário compatível com as horas a serem cumpridas durante o estágio e a simpatia da equipe escolar de receber a estagiária na instituição acadêmica.

Por meios cabíveis, para que toda a documentação e autorização de acesso à escola fosse formalizada, a Universidade de Brasília, a Regional de Ensino de Taguatinga Norte e a própria Escola Classe 49, contribuíram para que tudo funcionasse de maneira importante para o planejamento do estágio.

Portanto, o trabalho desenvolvido em sala de aula pela estagiária, procurou uma maneira de colaborar com o professor de turma e aperfeiçoar conhecimentos que só seriam adquiridos por meio da prática escolar. 


\subsection{A Escola Classe 49}

A Escola Classe 49 de Taguatinga situada na EQNL 17/19 - Área Especial - Taguatinga Norte - DF atende em média 350 alunos. Foi construída em 1986 e iniciou suas atividades, tendo como diretora a professora Simone.

Vale ressaltar que fatos importantes enriqueceram esta Instituição Educacional, como por exemplo, a criação do espaço reservado à leitura pela professora Maria Teixeira, homenageada com seu nome na sala de leitura construída, em 2001 na gestão da professora Maria dos Remédios, como também o espaço promovido pela professora Clarice para o culto a arte cênica e espaço criado pela professora Warly para jogos educativos "MEATECA".

Inicialmente a escola ofereceu apenas a educação básica de $1^{\mathrm{a}}$ à $6^{\mathrm{a}}$ série. No ano seguinte, 1987, foi implantado o pré-escolar, hoje denominado Educação Infantil: QMCM - Quanto Mais Cedo Melhor $-3^{\circ}$ Período.

Em 1997, de acordo com os princípios e filosofia da Escola Candanga houve ampliação parcial da carga horária, em apenas duas turmas de reintegração, do projeto CAA (Classe de Aceleração da Aprendizagem), que visa à aceleração dos alunos com defasagem na idade/ série.

Em 2000, houve a ampliação da carga horária, 5 horas/aula, sendo adotada a seriação como forma de agrupamento. Em julho de 2007 os alunos e funcionários forma transferidos, provisoriamente, para a E.C. 40 de Taguatinga, pois o prédio foi demolido, sendo construído um novo e inaugurado com a presença do Governador José Roberto Arruda no dia 11 de agosto de 2008 . 
Em 2009 a instituição educacional atendia turmas de Educação Infantil, Ensino fundamental de 9 anos até a $4^{\mathrm{a}}$ série, Ensino Especial e o Projeto Acelera do Instituto Ayrton Senna.

Relacionando algumas dificuldades enfrentadas pela escola, a mesma não possui autonomia, nem estrutura para trabalhar com o aluno todas as suas necessidades, não possui suficientes recursos como fonoaudiólogo e monitores para Educação Infantil. Mas para minimizar os prejuízos pedagógicos, gerados por esta situação, durante o ano são realizados projetos contemplando funcionários da escola, alunos e família tais como comemoração pelo Dia da Família, palestras, exposições, Festa Junina, Feira Cultural e gincana. A partir de eventos como estes, proporcionados pela instituição, as famílias dos alunos tendem a participar mais da vida escolar dos seus filhos, propiciando a valorização dos trabalhos realizados pela escola. Estes projetos explicitados são feitos a partir das opiniões de todos os professores da escola e visam evidenciar um trabalho interdisciplinar entre todas as matérias oferecidas pela instituição.

A Escola 49 é composta por doze salas de aula em boas condições físicas por conta da recente reforma ocorrida na instituição. Contém ainda uma sala de orientação educacional para atender os alunos, a sala dos professores para possíveis procedimentos dos profissionais da educação para a construção de planos de aulas e atividades, além da sala de coordenação pedagógica e outra da direção escolar que se responsabilizam pelo bom andamento do ambiente acadêmico nos aspectos físicos, pedagógicos e administrativos.

As crianças podem desfrutar do parquinho de areia para a hora do lazer, da brinquedoteca como forma de recreação, de uma sala de informática e também do ambiente destinado para a realização de leituras e exibição de vídeos voltados para a prática pedagógica 
adotada pela escola. A educação infantil utiliza dois banheiros, sendo um masculino e outro feminino, além de um banheiro adaptado para alunos portadores de necessidades especiais.

Os funcionários da instituição possuem a sala dos servidores para que haja a discussão entre eles sobre possíveis procedimentos de como melhorar o ambiente escolar para os alunos. Os mesmos possuem quatro banheiros, sendo dois masculinos e dois femininos, além do estacionamento interno e o acesso a cozinha para o preparo do lanche das crianças e de toda a equipe pedagógica.

A escola mantém uma sala de recursos com alguns materiais voltados para a área pedagógica, um almoxarifado, um depósito de materiais escolares, uma sala de apoio administrativo e uma secretaria/mecanografia.

A instituição de ensino é administrada por um corpo docente destinado a promover constantes melhorias para a escola e para o bem estar de seus alunos. Para isso conta com os recursos financeiros da APM (Associação de Pais e Mestres) de caráter voluntário, o PDAF (Programa de Descentralização Administrativa e Financeira) e o PDDE (Programa Dinheiro Direto na Escola).

A equipe pedagógica é composta pela diretora e vice-diretora. Conta ainda com duas supervisoras, uma pedagógica e outra administrativa. A escola possui ainda uma orientadora educacional e uma secretária. As duas educadoras são responsáveis também pela assistência educacional oferecida aos alunos.

Além da orientação pedagógica oferecida pelos profissionais que compõem a escola, há também a realização de projetos anuais que visam o trabalho de aperfeiçoamento das práticas pedagógicas adotadas pela instituição. Dentre eles podemos citar: $\mathrm{O}$ vídeo na 
educação; Sala de leitura; Brinquedoteca; A paz é a gente que faz ;Gente pequena fazendo história e Escola integral .

Como forma de instigar a participação das famílias dos alunos na escola, são promovidos eventos com as datas comemorativas para que toda a comunidade escolar juntamente com a equipe da instituição, se mobilize e dialogue sobre as questões históricoculturais presentes na vida do aluno e do ambiente no qual está inserido. Dentre as datas comemoradas mais importantes, destacamos: A Festa da família; Evento cultural relativo à festa junina; Dia das crianças; Feira cultural - Consciência negra.

A Escola Classe 49 passou por um processo de recuperação total das instalações físicas. A sua estrutura hoje conta com um ambiente agradável para os professores, os servidores e as crianças que lá estudam.

O contato inicial com a supervisora pedagógica foi muito importante, pois proporcionou uma boa visão da estrutura da instituição para que fosse dado início ao trabalho na escola. No primeiro dia, a servidora mais antiga em atividade, foi quem apresentou a estrutura da instituição.

O espaço da escola conta hoje com uma estrutura física em bom estado para a utilização dos alunos sendo doze salas de aula, todas limpas, com pouco tempo de uso. Os banheiros também são limpos e bem arrumados, sendo que os professores utilizam um banheiro específico.

Como a escola é inclusiva e precisa atender melhor aos alunos portadores de necessidades especiais, possui um banheiro apropriado para estes estudantes visando o bem estar destas crianças na escola. 
Uma sala foi separada para o momento de leitura, mas os professores não sabem ao certo se podem ou não chamar o lugar de biblioteca, pois não há um controle por parte da instituição na questão do empréstimo de livros para que os alunos pudessem levar as obras para a casa.

Há a sala dos servidores, a cantina de onde o lanche é distribuído para os alunos, a sala da coordenação (sala dos professores), a direção, uma sala que deveria ser destinada para aulas de informática, mas que ainda não funciona, um parquinho para as crianças menores usufruírem nos intervalos das aulas e uma brinquedoteca para que ali as crianças possam aprender brincando. É uma forma que utilizam para que os alunos desenvolvam não só a parte motora, mas também a parte cognitiva.

O ambiente escolar é de extrema importância para que o processo de ensino aprendizagem oferecido pela escola favoreça o desenvolvimento dos conhecimentos do aluno.

Os procedimentos de observação na escola foram inspirados nos estudos etnográficos porque essa perspectiva valoriza a questão da observação e do contato entre os participantes de um trabalho, no que tange à aproximação da realidade e da experiência vivenciada na escola.

Os estudos etnográficos são uma técnica, proveniente das disciplinas de Antropologia Social, que consiste no estudo de um objeto por vivência direta da realidade onde este se insere.

Tomemos inicialmente a pesquisa etnográfica para discutir suas implicações e vinculação com a educação. 
"A etnografia é um esquema de pesquisa desenvolvido pelos antropólogos para estudar a cultura e a sociedade. Para os antropólogos, o termo tem dois sentidos; (1) um conjunto de técnicas que eles usam para coletar dados sobre os valores, os hábitos, as crenças, as práticas e os comportamentos de grupo social; e (2) um relato escrito resultante do emprego dessas técnicas."1

O objetivo deste trabalho se encaixou neste perfil, uma vez que houve a presença da observação participante e a análise do processo.

A observação é participante, por evidenciar o papel do observador de interagir com a situação estudada e, por meio dela, intervir em determinadas questões obtidas a partir do contato com os sujeitos participantes da experiência. A análise do processo ocorre no decorrer do trabalho, com o principal objetivo de se compreender os resultados que a experiência de intervenção poderá trazer para a estagiária e os alunos.

Uma questão relevante apresentada por Marly André no livro Etnografia da Prática Escolar evidencia uma característica da pesquisa etnográfica de extrema importância para o trabalho de campo.

\begin{abstract}
"O pesquisador aproxima-se de pessoas, situações, locais, eventos, mantendo com eles um contato direto e prolongado. Como se dá esse contato? Primeiro não há pretensão de mudar o ambiente, introduzindo modificações que serão experimentalmente controladas como na pesquisa experimental. Os eventos, as pessoas, as situações são observadas em sua situação natural, o que faz que tal pesquisa seja também conhecida como naturalista". ${ }^{2}$
\end{abstract}

Este pequeno trecho resume o foco principal desta experiência, que é o da interação entre a estagiária, a professora Ângela e os alunos, por meio de práticas de leitura e suas consequências para o processo de compreensão leitora.

Através de contatos mais próximos com a escola foi possível perceber que mesmo que a instituição conte hoje com uma boa estrutura física, ainda faltam pequenas

\footnotetext{
${ }^{1}$ ANDRÉ, Marly Eliza D.A. de. Etnografia da prática escolar. 13. ed. Campinas, SP: Papirus, 1995. (Série Prática Pedagógica), p. 27.

${ }^{2}$ Ibidem, p. 29.
} 
coisas para um apoio material mais completo ao processo de ensino-aprendizagem. Uma delas seria a escola se apropriar de computadores e uma biblioteca para os alunos. Além de maior apoio material, a escola necessita de maior apoio da própria equipe escolar que precisa intensificar o trabalho pedagógico, de forma a valorizar e aprimorar o que a instituição já oferece e agregar através de discussões entre todos, maneiras de como melhorar a questão do ensino-aprendizagem por meio de mudanças a serem feitas no planejamento escolar.

A experiência de práticas docentes foi realizada em uma turma de $2^{\mathrm{a}}$ ano do ensino fundamental. A partir da aceitação da professora foi possível que o processo de conhecimento da turma começasse a ser feito.

$\mathrm{O}$ ato de estimular professores e todos os atores sociais envolvidos com educação, a pesquisar e optar por uma formação continuada, é um propósito que necessita de maior destaque no campo acadêmico, de maneira a valorizar os princípios que norteiam uma prática pedagógica voltada para a qualidade de ensino.

A partir de todo o processo de conhecimento do local e dos sujeitos integrantes desta experiência, o trabalho se desenvolveu com o propósito maior de contribuir para o processo de letramento das crianças com a realização de atividades para tal fim.

\subsection{Objetivo geral}

Depois de tomar contato com aspectos da estrutura e do funcionamento da escola deu-se prosseguimento ao objetivo geral traçado no desenvolvimento do projeto 4 , qual seja, analisar e intervir no trabalho de interpretação de textos em relação aos alunos em processo de alfabetização do ensino fundamental, a fim de colaborar para o processo de letramento desses estudantes, bem como discutir a importância das práticas de leitura no desenvolvimento da compreensão leitora. 


\subsection{Objetivos específicos}

Para atingirmos o objetivo geral, começamos pela formulação e análise dos seguintes objetivos específicos: Analisar quais as estratégias utilizadas pelo professor para trabalhar com textos em sala de aula; Conhecer as dificuldades de compreensão leitora dos alunos do $2^{\circ}$ ano do ensino fundamental; Analisar o material disponibilizado pela escola para o trabalho com gêneros textuais. Promover momentos significativos para a criança, quando a mesma estiver em processo de compreensão leitora. 


\section{A EXPERIÊNCIA NA ESCOLA}

Esta parte do trabalho tem por objetivo relatar como ocorreram os primeiros contatos entre a estagiária e os sujeitos da Escola Classe 49, bem como as primeiras impressões acerca das práticas docentes para o desenvolvimento da compreensão leitora.

A experiência foi realizada em uma escola da rede de ensino pública de Brasília, localizada em Taguatinga Norte, por ser uma instituição mais próxima à casa da estagiária, tendo facilitado as visitas e as intervenções nas aulas. A turma observada foi a do $2^{\mathrm{a}}$ ano do Ensino Fundamental e a professora responsável por administrar as aulas se chama Ângela.

\subsection{As participações e intervenções em sala de aula}

O primeiro dia de trabalho na Escola Classe 49 foi de fato, bastante proveitoso. A professora facilitou todo o andamento do processo de observação e participação. A mesma cursava faculdade de Pedagogia e trabalhava na escola há apenas seis meses por intermédio de contrato temporário com a Secretaria de Educação do Distrito Federal.

A aula começou com a correção dos exercícios feitos em casa pelas crianças. Logo depois, a atividade proposta pela professora foi a de abrir o livro didático e produzir tarefas relacionadas às artes. Primeiro, os alunos trabalharam com os nomes das cores e posteriormente começaram a pintar um mosaico localizado no final do livro utilizado. Algumas crianças possuíam dificuldade de aprendizagem e a professora não sabia o que fazer para que estas acompanhem bem as aulas. 
A estagiária corrigiu alguns cadernos, conversou e brincou com as crianças.

Como a aula foi mais para o desenvolvimento da parte motora e criativa dos alunos, todos participaram das atividades de pintura, depois lancharam e aproveitaram o momento do intervalo. Na volta do recreio, as crianças trabalharam com o caderno de desenho e fizeram um soldado em comemoração ao dia do soldado.

Para que de fato houvesse um diálogo entre a professora e a estagiária, foi preciso que este primeiro contato fosse pautado pelas questões de como seria a convivência daqui para frente e se haveria disponibilidade de trabalhar mais a leitura e a oralidade com os alunos.

Como a escola tinha um planejamento de como deveriam ser as atividades e projetos, além da questão da disponibilidade do tempo para a realização destas atividades durante o ano letivo, a professora em um primeiro momento teve resistência em aceitar as propostas do estágio. No entanto, como a escola dispõe de uma sala de leitura, foi possível convencer à educadora e a direção da escola de que poderiam ser desenvolvidas práticas de ler histórias e trabalhar com a interpretação de textos com os alunos, principalmente com os que apresentam uma maior dificuldade com a compreensão leitora, sendo este o argumento que as convenceu totalmente.

Tendo em vista este consentimento, foi possível refletir que o desenvolvimento da leitura e da escrita pelas crianças depende do grau de letramento da escola e do ambiente familiar. Tal qual nos diz KLEIMAN:

Sabemos que, inicialmente, o desenvolvimento de linguagem escrita, ou do processo de letramento da criança é dependente, por um lado, do grau de letramento das instituições sociais - família, escola, etc. - em que está inserida. Ou seja, da maior ou menor presença, em seu cotidiano, de práticas de leitura e de escrita. E, por outro lado, como ressalta de Lemos (1988: 11), seu processo de letramento será também dependente do seus "diferentes 
modos de participação (...) nas práticas discursivas orais em que estas atividades ganham sentido". ${ }^{3}$

\subsection{Mas o que é letramento mais apropriadamente?}

A palavra letramento não está ainda dicionarizada por ser recém-chegada ao vocabulário da educação e das ciências lingüísticas. É na segunda metade dos anos 80 que ela surge no discurso de especialistas dessa área.

Uma das primeiras ocorrências está em livro de Mary Kato de 1986 (No mundo da escrita: Uma perspectiva psicolingüística, Editora Ática), a autora, diz acreditar que a língua falada culta "é conseqüência do letramento". Dois anos mais tarde, em livro de 1988 (Adultos não alfabetizados: o avesso do avesso, Editora Pontes), Leda Verdiani Tfouni, no capítulo introdutório, distingue alfabetização de letramento: Talvez seja esse o momento em que letramento ganha estatuto de termo técnico no léxico dos campos da Educação e das Ciências Linguísticas. ${ }^{4}$

Letramento é, pois, "O resultado da ação de ensinar ou de aprender a ler e escrever: o estado ou condição que adquire um grupo social ou um indivíduo como conseqüência de ter-se apropriado da escrita" ${ }^{5}$. Nesse sentido, apropriar-se significa aprender a relacionar, interpretar e dialogar com o que se lê. É justamente neste instante que o papel da escola torna-se fundamental por ser um ambiente de aprendizagem e socialização, em que a criança começará a se tornar sujeito de sua própria história. Porém, nos diz KLEIMAN que:

[...] a escola, a mais importante das agências de letramento , preocupa-se, não com o letramento, prática social, mas com apenas um tipo de prática de letramento, a alfabetização, o processo de aquisição de códigos(alfabético, numérico), processo geralmente concebido em termos de uma competência individual necessária para o sucesso e promoção na escola. Já outras agências de letramento, como a família, a igreja, a rua como lugar de trabalho, mostram orientações de letramento muito diferentes ${ }^{6}$

Este fenômeno por não se restringir apenas a prática do ato de alfabetizar, precisa ser melhor trabalhado nas escolas de maneira a transmitir para as nossas crianças a

\footnotetext{
${ }^{3}$ KLEIMAN, Ângela B. Os significados do letramento: Uma nova perspectiva sobre a prática social da escrita. Campinas, SP: Mercado de Letras, 1995, p. 70.

${ }^{4}$ SOARES, Magda. Letramento: Um tema em três gêneros. 2. ed. Belo Horizonte: Autêntica, 2004, p. 15.

${ }^{5}$ Ibidem, p. 18.

${ }^{6}$ KLEIMAN, Ângela B. Os significados do letramento: Uma nova perspectiva sobre a prática social da escrita. Campinas, SP: Mercado de Letras, 1995, p. 20.
} 
importância da leitura para as suas vidas e não apenas a necessidade que esta possui no dia a dia.

\begin{abstract}
A principal tarefa da escola é ajudar o aluno a desenvolver a capacidade de construir relações e conexões entre os vários nós da imensa rede de conhecimento que nos enreda a todos. Somente quando elaboramos relações significativas entre objetos, fatos e conceitos podemos dizer que aprendemos. $^{7}$
\end{abstract}

A partir das relações de comprometimento da escola com os alunos, que a prática da leitura será evidenciada de forma importante e indispensável para todos. Para isso, é preciso um trabalho de extremo esforço para que as relações entre alunos e professores sejam estabelecidas por meio do respeito e da troca de experiências em sala de aula.

A segunda participação em sala de aula foi dedicada à matemática e a escrita dos números por extenso, como forma de aprimorar a aprendizagem dos alunos nesta área. Porém, antes de todo este processo, o início das atividades do dia começou na brinquedoteca. As crianças, que se divertem por meio dos jogos, puderam desenvolver a capacidade motora e a capacidade cognitiva no decorrer da visita a esta sala especial.

Logo quando a estagiária chegou, houve um momento importante de interação entre esta e os alunos, de forma a instigá-los a jogar em grupo e com a clareza de que perder também faz parte do jogo. Dentre os jogos vistos na sala, pôde-se perceber a variedade de brincadeiras que as próprias crianças inventaram a partir de objetos disponíveis para o uso. Na brinquedoteca havia varetas, quebra-cabeças, tampinhas, figuras, dentre outros. Foi perceptível o interesse dos alunos em jogar e também de ler as informações que continham em alguns tabuleiros. Apesar de a leitura não ser frequentemente trabalhada pela

\footnotetext{
${ }^{7}$ KLEIMAN, Ângela B.; MORAES, Silvia E. Leitura e interdisciplinaridade: Tecendo redes nos projetos da escola. Campinas: Mercado das Letras, 1999, p. 91.
} 
professora, foi possível perceber o gosto especial que as crianças tinham em relação ao ato de ler.

A escola possui uma pequena quantidade de livros da literatura infantil disponíveis para seus alunos, assim a professora faz o controle em sala de aula para saber quem leva qual livro para casa. Nesta aula, logo após trabalhar a contagem dos números de zero a cem e a escrita dos mesmos, a educadora do $2^{\circ}$ ano distribuiu os livros para cada estudante e colou nos seus respectivos cadernos, uma ficha que contém duas faces, uma com a imagem sorrindo e outra com a imagem de tristeza. O trabalho de leitura foi organizado da seguinte forma: se as crianças gostassem da história, deveriam marcar a face feliz, caso não gostassem do livro deveriam marcar a face triste. De certa forma, é um incentivo para a leitura sim, porém, deixa a desejar em relação à interpretação destas histórias e a relevância delas para a realidade dos alunos.

Em relação à leitura, por exemplo, é primordial que a criança comece a estabelecer sua maneira de compreender os livros, a partir do que gosta e julga significativo para a vida. O contexto de vida da criança deve ser encarado como uma forma de ponto de partida para instigar a aprender e seguir os passos mais importantes da trajetória de formação, que é saber ler, escrever e interpretar o mundo em que vive.

Essa falta de respeito pela bagagem existencial da criança tem conseqüências muito mais negativas do que geralmente se crê. Significa ignorar, por exemplo, tesouros da astúcia, toda a inventividade desenvolvida pelas crianças dos meios desfavorecidos para se defenderem das agressões de um mundo que tende a oprimi-las. ${ }^{8}$

Portanto, é tarefa dos pais e do ambiente escolar compartilhar com as crianças , desde cedo, o hábito da leitura e sua compreensão por meio de histórias, contos, poesias, fábulas e outros, para que a criança se torne no futuro um adulto capaz de cumprir

\footnotetext{
${ }^{8}$ http://www.sulear.com.br/texto06.pdf Acesso em: 10 nov. 10.
} 
plenamente o verdadeiro papel de cidadão na sociedade. Para isso, é preciso que se atente para a "leitura de mundo" que a criança pode fazer e socializar em outros ambientes como a escola.

Ao ambiente escolar sendo a principal "agência de letramento" da sociedade, cabe promover o letramento dessas crianças e contribuir para que a prática pedagógica oferecida esteja atrelada às vivências e sensibilidade de seus alunos.

Quando começou a aula de leitura em sala de aula, para que as crianças não acumulassem mais dever de casa, a estagiária teve uma maior oportunidade de interação com as mesmas. Um aluno já disse ter lido duas vezes a história, mas quando foi perguntado se era capaz de recontar o que leu, o comportamento mudou e a postura foi exatamente outra: "Tia, aí não sei”. A partir de tal fala, a curiosidade da estagiária em trabalhar com a interpretação de textos e a oralidade das crianças aumentou. E com o início de uma conversa, os alunos de forma paulatina foram interpretando e recontado, a seu modo, a história lida.

Resumindo, neste dia ficou absolutamente claro, que as crianças precisam interagir mais, tanto entre elas como entre elas e a professora, de maneira a alcançar melhores resultados no processo de alfabetização no qual se encontram. Isso foi percebido por conta de uma indagação da estagiária feita a professora: “Você trabalha com a interpretação de textos?" A professora disse: “Faz tempo que não faço isso com eles, mas já fizemos” e mostra um texto. Neste texto, as perguntas relacionadas a ele, eram simplórias e as respostas apareciam explícitas em cada fragmento, fato que empobrece a capacidade que as crianças possuem de falar, inferir e relacionar e articular questões de sua experiência de vida com a leitura sugerida.

\footnotetext{
${ }^{9}$ KLEIMAN, Ângela B. Os significados do letramento: Uma nova perspectiva sobre a prática social da escrita. Campinas, SP: Mercado de Letras, 1995, p. 20.
} 


\subsection{Plano de aula: A União}

A partir do que foi visto na última aula em relação ao trabalho de leitura feito pela professora foi imprescindível para que esta terceira participação fosse um momento especial e dinâmico com as crianças. Para isso, a estagiária sugeriu à professora Ângela, um plano de aula que teve como objetivo trabalhar com temas que a própria escola promove e que faz parte da realidade do aluno não só na escola, mas também na vida cotidiana, como os valores. Para a aula, foi enfatizada a união, sendo esta uma das bases da existência, pois enquanto nos conservarmos unidos e um velar pelo bem-estar do outro, estará assegurado o bem de todos.

O trabalho desempenhado a partir do tema união, teve como pressuposto a participação e a interação entre os sujeitos envolvidos, de maneira a fazê-los perceber a tamanha importância da união no dia a dia.

Assim, o objetivo geral desta aula foi o de dinamizar o momento de aula, de forma a contar histórias, instigar a capacidade motora e cognitiva dos alunos e, principalmente, prezar pela participação e produção textual de todos. Já os objetivos mais específicos foram pautados na direção de uma participação ativa dos alunos; Instigar a participação e a cooperação de maneira a evidenciar a união entre todos; Evidenciar a importância do outro em nossas vidas.

A partir dos objetivos traçados, passamos para a metodologia utilizada:

A aula foi composta por dois momentos: primeiro ocorreu a leitura de uma história evidenciando a união e depois uma dinâmica de encerramento. 
Foi contada uma história sobre a união com a presença de um fantoche, de maneira a instigar a participação de todos. Desta forma, todos produziram um desenho e uma mensagem criativa que evidenciou o tema trabalhado.

Puderam ser observados nos desenhos apresentados que em sua maioria continham aspectos e mensagens escritas que denotavam a família, os amigos dentro e fora da escola, o relacionamento com as professoras e etc. Notou-se, portanto, que as crianças já possuíam uma capacidade de interpretar a história contada, bem como representar pessoas e situações que elas convivem no dia a dia relacionando com o tema sugerido para a aula, pois como bem nos aponta Vygotsky, (1998), o desenho da criança ocupa um lugar importante no desenvolvimento de sua função simbólica, e do que o autor vai chamar de pré-história da linguagem escrita.

K.Buhler notou, corretamente, que o desenho começa quando a linguagem falada já alcançou grande progresso e já se tornou habitual na criança. Em seguida, diz ele, a fala predomina no geral e modela a maior parte da vida interior, submetendo-a a suas leis. Isso inclui o desenho ${ }^{10}$.

A criança começa um processo de representação daquilo que vive por meio do desenho, sendo seus desenhos, portanto, mais simbolistas do que naturalistas.

Achamos que Hetzer está muito certo ao afirmar que a representação simbólica primária deve ser atribuída à fala e que é utilizando-a como base que todos os outros sistemas de signos são criados. De fato, também no desenvolvimento do desenho nota-se o forte impacto da fala, que pode ser exemplificado pelo deslocamento contínuo do processo de nomeação ou identificação para o início do ato de desenhar ${ }^{11}$

Por meio deste processo do desenho, evidenciado durante o trabalho com crianças do ensino fundamental, é possível afirmar que a forma de representação da linguagem falada através do desenho, é uma maneira de percebermos a capacidade da criança

\footnotetext{
${ }^{10}$ VYGOTSKY, Lev Semenovich. A formação social da mente. O desenvolvimento dos processos psicológicos superiores. 6. ed. 1998, p. 148.

${ }^{11}$ Ibidem, p. 150.
} 
de desenvolver, a partir de sinais simbólicos abstratos, as descobertas que vão surgindo ao longo da vida escolar e de como nós educadores podemos considerar este processo como significativo para que a criança comece a se apropriar da escrita e da leitura.

A compreensão da linguagem escrita é efetuada, primeiramente, através da linguagem falada; no entanto, gradualmente essa via é reduzida, abreviada, e a linguagem falada desaparece como elo intermediário. A julgar pelas evidências disponíveis, a linguagem escrita adquire o caráter de simbolismo direto, passando a ser percebida da mesma maneira que a linguagem falada. Basta imaginarmos as enormes transformações que ocorrem no desenvolvimento cultural das crianças em conseqüência do domínio e do processo de linguagem escrita e da capacidade de ler, para que nos tornemos cientes de tudo que os gênios da humanidade criaram no universo da escrita. $^{12}$

No entanto, torna-se imprescindível que tomemos como discussão a relação

entre três fatores indissociáveis.

Primeiro, que nós educadores tomemos como consciência que o ensino tem de ser organizado de forma que a leitura e a escrita se tornem necessárias às crianças. Isto porque a maneira mecânica de escrever torna-se pouco produtiva e instiga menos a capacidade de criação de alunos que começam a ascender no mundo da leitura e precisam escrever a partir do desenvolvimento desta compreensão leitora.

Se forem usadas apenas para escrever congratulações oficiais para os membros da diretoria da escola ou para qualquer pessoa que o professor julgar interessante (e sugerir claramente para as crianças) então o exercício da escrita passará a ser puramente mecânico e logo poderá entediar as crianças; suas atividades não se expressarão em sua escrita e suas personalidades não desabrocharão. ${ }^{13}$

Segundo, a escrita deve ser algo intrínseco à vida das crianças, é preciso que elas percebam a relação que se estabelece entre a leitura e suas próprias vidas para que o ato de escrever seja um hábito necessário para o desenvolvimento da linguagem.

\footnotetext{
${ }^{12}$ VYGOTSKY, Lev Semenovich. A formação social da mente. O desenvolvimento dos processos psicológicos superiores. 6. ed. 1998, p. 154.

${ }^{13}$ Ibidem, p. 156.
} 
Terceiro, a escrita precisa ser ensinada naturalmente, nada precisa ser imposto para que a criança venha a desenvolver sua capacidade de ler e escrever. O que tornase fundamental, é o cultivar por meio de instrumentos, como o próprio brinquedo e outros artifícios pedagógicos, as habilidades que cada criança possui a partir do trabalho a ser feito ao longo da vida escolar.

Os educadores devem organizar todas essas ações e todo o complexo processo de transição de um tipo de linguagem escrita para outro. Devem acompanhar esse processo através de seus momentos críticos, até o ponto da descoberta de que se pode desenhar não somente objetos, mas também a fala. Se quiséssemos resumir todas essas demandas práticas e expressá-las de uma forma unificada, poderíamos dizer que o que se deve fazer é ensinar às crianças a linguagem escrita, e não apenas a escrita de letras. ${ }^{14}$

Logo depois, uma dinâmica foi executada, agora com a ajuda de balões. Cada aluno recebeu um balão, sendo convidados, antes de enchê-lo, a escrever em um pedaço de papel uma frase sobre a união. Feito isso, colocaram dentro do balão e encheram. Todos trabalharam juntos no sentido de jogarem os balões para cima e não deixarem cair. Nesta hora, quem tivesse dificuldade contaria com o colega. No final da atividade, cada criança leu a frase que continha nos balões e falaram da importância da união dentro e fora da escola.

Nesta aula foram utilizados além da sala de aula e o pátio da escola como recursos físicos, o fantoche, livro, folhas A4 e balões como recursos didáticos, bem como cerca de cinco horas para o desenvolvimento das atividades. A avaliação se deu pela capacidade de interação e participação da turma.

O momento da aula foi significativo para a estagiária e também para os alunos e a professora, pois as crianças puderam trabalhar com a significação das palavras acerca do tema União e trabalharam em grupo para que os balões não caíssem.

\footnotetext{
${ }^{14}$ VYGOTSKY, Lev Semenovich. A formação social da mente. O desenvolvimento dos processos psicológicos superiores. 6 . ed. 1998, p. 157.
} 
As dinâmicas sugeridas foram bem aceitas pela turma e todos interagiram. Durante a aula foi possível trabalhar com os conceitos de união, de maneira a evidenciar a capacidades que todos têm de se relacionar e trabalhar em grupo.

Como último momento da aula, foi proposta uma da roda da conversa sobre a história contada pelo fantoche, sendo perceptível perceber que as crianças compreenderam a mensagem de união e trocaram experiências vivenciadas no dia a dia relacionadas a este tema.

Como dever de casa, todos tiveram como tarefa desenhar sobre o tema união e escrever uma frase relacionada ao tema para a próxima aula. Diante deste exercício, a professora incentivou para que fossem realizadas outras atividades similares a esta desenvolvida.

Embora alguns alunos tenham se envolvido mais e outros menos, as atividades propostas foram uma forma de incentivar todos que compõem e são importantes para que haja de fato a verdadeira construção do conhecimento na escola. Por meio da troca de opiniões, da leitura de textos do universo infantil e da escrita, com certeza a credibilidade e a autoestima destes alunos foram evidenciadas.

\subsection{Dinâmica dos líderes}

Em outra atividade, a estagiária e a professora da turma do $2^{\circ}$ ano, propuseram aos alunos uma temática diferente para o dia. A atividade desempenhada foi a de evidenciar e reforçar a idéia de união e respeito entre os colegas. Para isso, a dinâmica da aula foi a de eleger líderes e nomes para grupos, de maneira a fazer com que os alunos permaneçam no mesmo grupo até o fim do ano. 
O trabalho começou com a distribuição de fichas para a turma com o objetivo de fazê-los refletir sobre três indagações:

- Com quem quero aprender...

- Com quem quero trocar...

- A quem quero ensinar...

A metodologia utilizada foi a seguinte: Logo após o recolhimento das fichas, alguns nomes de alunos foram citados e anotados no quadro negro para que desse início a apuração dos votos com a participação de toda a turma. Consequentemente, os mais votados seriam os líderes.

Com a formação dos líderes, estes foram até a frente da sala e começaram a escolher quem gostariam que fizesse parte de seus grupos. Após a formação dos seis grupos, cada um teve a tarefa de escolher um nome para a sua equipe permanente. Para esta atividade, as crianças tiveram bastante criatividade e deram boas idéias de nomes. Dentre eles: Falcão, Rosas, Águia, etc.

O objetivo da dinâmica foi o de evidenciar a capacidade que todos têm de interagir e ajudar os colegas que possuem alguma dificuldade de aprendizagem. Foi perceptível a mudança de comportamento diante destes problemas e um começo para a solução dos mesmos. Para a continuidade da aula, livros de leitura foram distribuídos aos grupos, de maneira a fazê-los trocar em sala de aula as histórias infantis, bem como a tarefa de destacar as palavras chaves. Foi um dia positivo por evidenciar a participação das crianças e também destacar a interação entre elas e a professora. 


\title{
4.5 Apresentação e interpretação do filme infantil - Ratatouille
}

$\mathrm{Na} 4^{\mathrm{a}}$ participação em aula, o foco foi assistir a um filme de animação chamado Ratatouille e propor para as crianças um momento de discussão do filme e sua interpretação. Para situar melhor a história contada pelo filme segue sua sinopse:

\begin{abstract}
Um rato chamado Remy sonha em se tornar um grande chefe francês, mesmo contra os desejos de sua família e do óbvio problema de ser um rato em uma profissão totalmente inapropriada para roedores. Quando o destino o leva aos esgotos de Paris, Remy se vê na situação ideal, bem embaixo do famoso restaurante de seu herói culinário, Auguste Gusteau. Apesar dos aparentes perigos de ser um inadequado - e certamente indesejado visitante na cozinha de um fino restaurante francês, a paixão de Remy pela arte culinária não demora a colocar em marcha acelerada uma engraçadíssima e eletrizante corrida de ratos que invade o mundo da culinária parisiense. Remy então se sente dividido entre sua vocação e a obrigação de voltar para sempre à sua prévia existência de rato. Ele aprende a verdade sobre amizade, família e entende que sua única opção é a de aceitar quem ele é realmente: um rato que deseja ser chefe de cozinha. ${ }^{15}$
\end{abstract}

Os filmes infantis compõem o imaginário infantil e, por isso, são relevantes para o processo educativo das crianças. A temática natureza é usual nesses filmes e, nos últimos anos, tem sido possível evidenciar um viés aparentemente mais crítico sobre a relação natureza e sociedade. De modo direto ou subliminar, os roteiros contêm informações e disposições de pensamento sobre a referida relação, contribuindo para as representações sociais das crianças.

A partir da temática trabalhada no filme, o objetivo foi fazer com que as crianças conseguissem enxergar os personagens, seus valores, quais os caminhos que cada um seguiu durante a trama.

Logo após a exibição do filme, as crianças puderam falar sobre os personagens e a mensagem trazida pela animação, bem como puderam realizar desenhos e frases.

\footnotetext{
${ }^{15} \mathrm{http}: / /$ www.interfilmes.com/filme 16453 Ratatouille-\%28Ratatouille\%29.html Acesso em: 10 nov.
} 10 . 
A partir das ideias expostas e com a ajuda da professora da turma, foi possível fazer uma atividade de interpretação do filme, de maneira a não só fazer perguntas óbvias ou explícitas sobre o mesmo, mas de instigar as crianças a falarem e a concordarem ou não com o que viram. O desenvolvimento do senso crítico desde cedo, pode ser uma forma que envolva melhor os alunos na atividade proposta.

A interpretação de filmes também é de suma importância para que alunos de séries iniciais percebam as várias possibilidades de interpretação de uma história, se já passaram por algo parecido ou até mesmo se tem outras histórias com temas semelhantes para contar.

Todos tiveram a oportunidade de falar, de trabalhar a oralidade, de expressar o gosto por algum personagem e justificarem o porquê, de recontarem a história assistida, de comparar o filme com a vida deles ou de algum conhecido.

Foi um trabalho agradável de ser feito, pois a partir das produções textuais e também da opinião de cada aluno acerca do filme, a conclusão tirada é a de que todos são capazes de expressar ideias, de inferir coisas, de relacionar temas e não se restringir apenas as cenas engraçadas.

Torna-se necessário que as crianças trabalhem com temáticas de filmes para que possam relacionar a história com a sua própria realidade social e também com outras histórias.

O filme ajuda a compreender algumas concepções de Vygotsky quando mostra como a linguagem vai dando forma ao pensamento e a relação entre as interações humanas, a aprendizagem e o desenvolvimento. 
A concepção do desenvolvimento intelectual de Vygotsky, sustenta que todo conhecimento é construído socialmente, no âmbito das relações humanas. Essa concepção tem por base o desenvolvimento do indivíduo como resultado de um processo sócio-histórico, enfatizando o papel da linguagem e da aprendizagem nesse desenvolvimento.

\subsection{O trabalho de compreensão da história cantada: "A Tartaruga Amiguinha"}

$\mathrm{Na}$ aula seguinte, dando continuidade ao trabalho dentro do projeto da escola intitulado "Valores", a estagiária teve o papel de contar uma história cantada por meio de imagens. A história conta com a reflexão de sempre ajudar o outro para assim também ser ajudado, as crianças gostaram muito da aula e puderam levar um pouco dela para as suas próprias realidades.

O objetivo geral desta atividade foi o de enfatizar a questão dos valores por meio da interpretação da história da amiga tartaruga. E os objetivos específicos foram os de incentivar a participação ativa das crianças durante a interpretação da história contada; trabalhar além da oralidade, a capacidade motora dos alunos e a produção artística relacionada ao tema valores.

A metodologia utilizada foi a de no início da aula relembrar sobre o tema "Valores", já trabalhado anteriormente com a questão da união e das dinâmicas propostas em aulas anteriores. Logo após este momento, cartazes com as imagens da história da tartaruga foram colados no quadro negro para que as crianças conseguissem visualizar e interpretar melhor toda a história.

A “Tartaruga Amiguinha” é uma música que vem contar a história de uma tartaruga que queria conhecer o mundo e que no meio do caminho conhece novos amigos e 
conta com mensagens de companheirismo e da importância de ajudar o outro, tendo como uma das frases de maior atenção a de "ajudar para ser ajudado".

Logo após a história, as crianças tiveram a oportunidade de falar e dar a opinião referente ao que foi apresentado, todos gostaram e produziram uma tartaruga com o uso de garrafas plásticas trazidas por eles mesmos.

A aula foi significativa tanto para a estagiária como para os alunos, pois teve como principal objetivo enfatizar como deve ser a convivência em sala de aula, para que seja um espaço de amizade, harmonia e afetividade entre todos. Dentre os recursos utilizados, podem se destacar a sala de aula como espaço físico, cartazes, tesoura, papel camurça, garrafas de plástico; som como recurso didático e; 5 horas para a realização destas atividades. A avaliação ocorreu a partir da valorização da oralidade e da interpretação das crianças acerca da história e a produção artística das tartarugas.

A descoberta de que o significado das palavras evolui tira o estudo do pensamento e da linguagem de um beco sem saída. Os significados das palavras passam a ser formações dinâmicas e não já estatísticas, transformam-se à medida que as crianças se desenvolvem e alteram-se também com as várias formas como o pensamento funciona. ${ }^{16}$

Dessa forma, o desenvolvimento do pensamento está conectado com o desenvolvimento da linguagem, através do desenvolvimento dos significados das palavras e pela experiência sociocultural da criança. Durante a roda da conversa com os alunos sobre a história cantada foi possível perceber que muitas das crianças utilizaram suas próprias palavras e a representação de desenhos para relacionar o tema amizade com suas próprias vivências e adquirir outros significados para as mesmas.

\footnotetext{
${ }^{16} \mathrm{http}: / /$ www.ebooksbrasil.org/eLibris/vigo.html\#ind10, Acesso em 10 nov. 10.
} 


\subsection{A utilização da biblioteca}

A aula seguinte teve início a partir do momento de leitura proposto aos alunos do $2^{\circ}$ ano do ensino fundamental. Para tanto, a escola disponibilizou a utilização da biblioteca composta por livros infantis de literatura que proporcionou um ambiente tranqüilo, silencioso e agradável para a prática da leitura aos estudantes.

Alguns alunos ficaram agitados, outros se dedicaram mais à leitura. A dinâmica neste dia foi a de incentivar a capacidade da criança de ler, interpretar a história e recontá-la para os demais colegas.

Logo após a visita a biblioteca, os alunos voltaram para a sala de aula e começaram outra atividade. A professora Ângela ditou dezoito palavras que faziam parte do universo significativo das crianças, dos livros lidos por elas na biblioteca e também do cotidiano para que os alunos pudessem escrever corretamente de acordo a norma padrão da língua portuguesa. Com o auxílio da estagiária, foi possível corrigir caderno por caderno até que todos compreendessem onde haviam errado e como poderiam corrigir os erros.

Tornou-se perceptível a dificuldade de alguns alunos para a correta formação de palavras que continham os encontros consonantais "lh", "nh", "rr" e "ss". Muitos erraram palavras que são utilizadas no próprio cotidiano.

O professor identifica "erros de leitura", isto é, erros na decodificação do material que está sendo lido, mas não faz distinção entre diferenças dialetais e erros de decodificação na leitura, tratando-os todos da mesma forma. ${ }^{17}$

A dificuldade de compreender a diferença de quando se fala e se escreve é o que mais se fez presente na atividade. Destaco aqui a iniciativa da professora de ter levado

\footnotetext{
${ }^{17}$ BORTONI-RICARDO, Stella Maris. Educação em língua materna. A sociolinguística na sala de aula. Parábola Editorial, 2006, p. 38.
} 
livros da biblioteca para a sala de aula para que as crianças pudessem observar as palavras e, a partir delas, trabalharem com a interpretação por meio da compreensão leitora, sendo fundamental o incentivo de nós professores de enfatizar a importância da leitura significativa no processo de decodificação das palavras.

\subsection{A leitura de mundo}

No fragmento de entrevista entre Paulo Freire e Marcio Campos, intitulada "Leitura da Palavra, Leitura do Mundo", o pedagogo Paulo Freire conversa com o etnocientista e educador Marcio Campos, a respeito da autêntica educação marcada pela aprendizagem da leitura e escrita equivalente a uma "releitura" do mundo.

A criança estabelece sua própria maneira de aprender por meio de suas próprias vivências e percepções do que a cerca no cotidiano. Desde os primeiros anos na escola, as crianças começam a socializar neste novo ambiente com outras pessoas, um pouco do seu universo no que se refere a família, a cultura e aos aspectos considerados significativos para a construção de uma educação sólida e eficiente ao longo da vida. "Essa primeira leitura do mundo leva a criança a exprimir, mediante signos e sons, o que ela aprendeu do universo que a cerca". ${ }^{18}$

Sendo assim, torna-se imprescindível que nós educadores tenhamos a sensibilidade de trabalhar com os alunos em sala de aula a questão dos conteúdos e práticas pedagógicas a partir da "leitura de mundo" que eles têm acerca do que já viveram e vivem em relação ao contexto de vida no qual estão inseridos.

[...] o ensino deve sempre respeitar os diferentes níveis de conhecimento que o aluno traz consigo à escola. Tais conhecimentos exprimem o que poderíamos chamar de a identidade cultural do aluno-ligada, evidentemente, ao conceito sociológico de classe. $\mathrm{O}$ educador deve considerar essa "leitura

\footnotetext{
${ }^{18}$ http://www.sulear.com.br/texto06.pdf Acesso em: 10 nov. 10.
} 
do mundo" inicial que o aluno traz consigo, ou melhor, em si. Ele forjou-a no contexto de seu lar, de seu bairro, de sua cidade, marcando-a fortemente com sua origem social. ${ }^{19}$

\footnotetext{
${ }^{19} \mathrm{http}: / /$ www.sulear.com.br/texto06.pdf Acesso em: 10 nov. 10.
} 


\section{ALGUMAS REFLEXÕES}

Desta forma, o presente trabalho demonstra que a capacidade de aprendizagem do indivíduo em fase de alfabetização é impulsionada diretamente pelas principais agências de letramento, como a família e a escola na medida em que suas ações e omissões são capazes de melhor ou pior influenciar o aprendizado.

A partir de outra perspectiva, as propostas discutidas por meio deste trabalho, exigem que o leitor reflita um pouco mais sobre a questão da leitura nas escolas e de como a equipe educacional pode melhorar as maneiras de atingir um objetivo final e comum, como o desenvolvimento de leitores competentes e o despertar pela capacidade de realização das atividades de leitura.

Para que haja de fato uma abordagem clara e objetiva sobre alfabetização e letramento, retratados nesta experiência, é importante saber o que os difere, pois como assinala Kleiman:

Ser alfabetizado significa, poder assinar o nome e reconhecer as letras do alfabeto. A diferença entre ser alfabetizado e letrado implica diferenças no grau de familiaridade com diversos usos a escrita do cotidiano. $\mathrm{O}$ indivíduo plenamente letrado também é capaz de desfrutar de um romance, de um poema. É função da escola formar sujeitos letrados, não apenas alfabetizados. ${ }^{20}$

A leitura torna-se uma das maneiras que a escola possui para a contribuição da diminuição da injustiça social em sociedade. Isto, se fornecer oportunidade de acesso ao saber para todos independente de classe social, raça e cultura.

\footnotetext{
${ }^{20}$ KLEIMAN, Ângela B.; MORAES, Silvia E. Leitura e interdisciplinaridade: Tecendo redes nos projetos da escola. Campinas: Mercado das Letras, 1999, p. 90.
} 
Ainda a respeito da questão de ser letrado em nossa sociedade, pode-se começar a construir o conceito de letramento mais especificamente e sua valiosa contribuição, a partir das peculiaridades que o difere e o relaciona com o ato de alfabetizar.

Ser analfabeto é não saber ler e escrever, porém, saber ouvir a leitura feita por terceiros, ditar palavras e frases para que outros escrevam e folhear livros, são formas de percebermos que pessoas ditas analfabetas, são letradas, pois estão inseridas no mundo do letramento. Mundo este que evidencia as práticas sociais de leitura e estabelece o modo de vida das pessoas que vivem e convivem com situações nas quais estão presentes a leitura e a escrita.

Seja para viajar de ônibus, entender propagandas em outdoors, estabelecer relações sociais, fazer representações do que se vê e se interpreta, são maneiras de se perceber a vida em sociedade e de que tudo ou grande parte que nos rodeia, favorece para a criança, desde cedo, começar a perceber as possibilidades que possui de criar, fantasiar e interpretar o mundo em que vive. Ou seja, comece a ser inserida no mundo do letramento.

O objetivo maior deste trabalho foi o de descrever situações em sala de aula em que foi possível contribuir para a prática do letramento das crianças. Por meio do estágio realizado na escola Classe 49 , as mudanças desencadeadas pela estagiária nas aulas de leitura e escrita foram positivas para aquele ambiente. A turma composta por alunos em processo de alfabetização obteve possibilidades maiores de exercitar a capacidade leitora, a oralidade e participação, que antes não aconteciam por timidez de grande parte dos alunos ou até mesmo, por medo de serem ridicularizados por expressarem suas opiniões e bagagem cultural no ambiente escolar. 
As várias atividades propostas puderam ajudar no contexto educacional e foram bem utilizadas a partir de várias possibilidades como o incentivo aos alunos para o pintar; o desenhar no contexto da história; discutir sobre as partes da história que as crianças mais gostaram; trocar experiências a partir da história contada; adivinhar o que vai acontecer e imaginar finais e situações diferentes; colar; usar materiais de artes; usar bexiga; construir personagens da história interpretada; elaborar textos; trabalhar em grupo, dentre outras, puderam contribuir para a formação de um ser criativo, crítico, imaginativo, companheiro e provavelmente leitor.

Nós, educadores comprometidos e atuantes na área de leitura e escrita, temos a valiosa tarefa de conhecer nossos alunos, compreendê-los e inseri-los num novo universo em que o educador deverá incentivar a interação entre todos, pois a prática da leitura se faz presente em nossas vidas desde o momento em que começamos a "compreender" o mundo à nossa volta.

Assim, por meio da interatividade, torna-se possível aprender a ler, escrever e compreender as leituras que levarão as crianças a descobrirem elas mesmas de forma prazerosa e contínua.

Torna-se imprescindível destacar que este trabalho contou com o apoio da Escola Classe 49, bem como com toda a sua equipe de profissionais que colaborou de forma significativa para a construção deste trabalho. Apesar da falta de tempo para a realização das atividades durante estágio, foi possível construir um vínculo de respeito e afetividade com as crianças e a professora de maneira a proporcionar para a estagiária, momentos de aprendizagem e de significativo valor para a formação como pedagoga. Por meio desta experiência foi possível perceber que trabalhar com a leitura em sala de aula é um grande 
desafio para nós professores por ser uma temática que requer maior dedicação e interatividade com as crianças.

Ler e compreender o que leu é um trabalho que precisa ser reforçado sempre em sala de aula de forma a instigar os futuros leitores a interpretarem textos e escrever a partir desta interpretação. O primeiro passo de como inserir o hábito da leitura foi dado a partir das atividades e da relação que se estabeleceu entre a estagiária e as crianças. Torna-se indispensável que este trabalho continue e venha a proporcionar cada vez mais oportunidades para as nossas crianças que devem usufruir de livros e de espaços próprios como a manutenção de bibliotecas e serviços de empréstimos de obras literárias.

Com relação às estratégias utilizadas pela professora Ângela para trabalhar com textos em sala de aula, considero que os métodos utilizados não foram satisfatórios no que se refere a instigação dos alunos a prática da leitura de livros, tendo em vista que em raros momentos, os alunos eram levados à refletir sobre o que liam e escreviam, sendo um trabalho estritamente mecânico, e nos momentos em que havia disponibilidade para se interpretar textos ou histórias as perguntas utilizadas pela professora possuíam respostas explícitas e pouco contribuíam para melhorar a capacidade de interpretação das crianças.

Por outro lado, por meio das observações e intervenções feitas ao longo do estágio na escola, foi possível trabalhar a prática da compreensão leitora com os alunos e presenciar o crescimento do processo das práticas de leitura pelas crianças e também a valorização dessas práticas pela professora, apesar da insuficiência de material disponibilizado pela escola e da pouca utilização que as crianças fazem do espaço da biblioteca e da ausência do serviço de empréstimo de livros. 
Apesar dos aspectos negativos citados acima, considero que o trabalho realizado na Escola Classe 49 foi significativo para a vida dos alunos e para o meu desenvolvimento como pedagoga, pois por meio dos momentos de intervenção assinalados neste trabalho, as crianças se mostraram aptas e capazes para a interpretação de textos, representação em forma de desenhos e puderam relacionar o que vivenciavam fora do ambiente escolar com os temas trazidos para a sala de aula. 


\section{CONSIDERAÇÕES FINAIS}

Todo este trabalho foi norteado pela questão de como intervir nas séries iniciais do ensino fundamental, no que se refere à alfabetização e letramento dos alunos. As discussões estabelecidas ao longo deste trabalho monográfico nos permitiu alcançar o objetivo proposto: Analisar a questão da compreensão leitora de um grupo de alunos do $2^{\circ}$ ano do Ensino Fundamental pertencentes a Escola Classe 49.

Assim, na parte introdutória apresentamos a minha trajetória escolar ao longo da vida acadêmica, sendo este o primeiro passo que permitiu se chegar ao curso de Pedagogia na Universidade de Brasília e, a partir de tal feito, escolher disciplinas, projetos, autores e professores que serviram de base para a construção deste trabalho acerca da leitura e sua aplicação prática em sala de aula.

No entanto, temos como destaque para a escolha do tema: a compreensão leitora de alunos do ensino fundamental, a realização do projeto quatro que permitiu a chegada até a Escola Classe 49 onde foram realizadas as observações e intervenções da estagiária nas aulas, com ênfase no processo de letramento dos alunos.

Assim sendo, vale ressaltar que a escola é a principal "agência de letramento" ${ }^{21}$ da sociedade. Desse modo, uma de suas funções é a de contribuir para que os estudantes tenham a oportunidade de ampliar e agregar novos conhecimentos por meio das práticas letradas tendo acesso a textos que circulam na sociedade e as atividades significativas para a vida em torno da leitura.

\footnotetext{
${ }^{21}$ KLEIMAN, Ângela B. Os significados do letramento: Uma nova perspectiva sobre a prática social da escrita. Campinas, SP: Mercado de Letras, 1995.
} 
A partir destas observações, a estagiária contribuiu para que as intervenções feitas na Escola Classe 49 fossem significativas no âmbito da leitura, de maneira a inserir as crianças em processo de alfabetização no mundo do letramento e do prazer de compreender um texto, um filme ou um livro, com base na "leitura de mundo" ${ }^{22}$ da criança e auxiliar para que os novos conhecimentos fossem agregados aos que os alunos já possuíam no decorrer das intervenções na escola.

Formulamos a partir da descrição do ambiente visitado e das ações que poderiam ser realizadas, o nosso objetivo geral de analisar e intervir no trabalho de interpretação de textos em relação aos alunos em processo de alfabetização do ensino fundamental, a fim de colaborar para o processo de letramento destes estudantes. Os objetivos específicos foram os de analisar quais as estratégias utilizadas pelo professor para trabalhar com textos em sala de aula; Conhecer as dificuldades de compreensão leitora dos alunos do $2^{\circ}$ ano do ensino fundamental; Analisar o material disponibilizado pela escola para o trabalho com gêneros textuais; Promover momentos de entretenimento para a criança, quando a mesma estiver em processo de compreensão leitora, que guiaram nosso trabalho.

No decorrer do trabalho, descrevemos os primeiros contatos da estagiária com a instituição e a equipe escolar, de forma a contextualizar a escola, os recursos financeiros, físicos e administrativos que dispõe e os projetos anuais promovidos com a finalidade de melhorias para a questão do letramento e participação dos pais das crianças na escola.

A partir do conhecimento acerca da instituição e da turma na qual foi realizado o trabalho, foram descritos os encontros da estagiária com a turma e as intervenções feitas ao longo do tempo da experiência. O planejamento e desenvolvimento das atividades

\footnotetext{
${ }^{22}$ http://www.sulear.com.br/texto06.pdf Acesso em: 10 nov. 10.
} 
realizadas foram de grande incentivo para que os alunos fossem inseridos de forma significativa no mundo do letramento.

Por meio das aulas propostas, muitos dos alunos começaram a ver as histórias de livros, filmes e textos dos livros didáticos, de uma forma diferente. Isto porque já conseguiam colocar suas opiniões e socializar com os colegas com mais liberdade a respeito das leituras sugeridas. As crianças começaram a perceber que sua compreensão leitora é importante, que o que elas tinham a dizer é relevante para a aula. Por esse motivo, até mesmo os alunos com um nível de timidez mais elevado, conseguiam participar mais das aulas e dar sua contribuição a partir do que entenderam sobre os textos. Fato este, de extrema satisfação para a estagiária e para a professora.

$\mathrm{Na}$ terceira parte do trabalho, discutimos as questões relevantes acerca da experiência e das conclusões acerca das estratégias pedagógicas utilizadas pela estagiária sobre compreensão leitora e os resultados obtidos. Percebemos que, apesar da falta de tempo e de algumas interrupções relatadas ao longo do trabalho por conta de outras atividades que precisavam ser concluídas pela turma, os objetivos foram alcançados e o interesse pela leitura, por parte dos alunos, aumentou de forma significativa, bem como a participação das crianças nas aulas e o reconhecimento da professora Ângela.

Esta experiência na Escola Classe 49 serviu como base para que a instituição junto com o corpo docente e os demais funcionários realize um maior diálogo nas reuniões promovidas pela escola, por meio dos conselhos de classe, a questão da leitura e das maneiras diferentes de como podem trabalhá-la em sala de aula. 


\section{PERSPECTIVAS PARA O FUTURO}

O presente estudo monográfico trouxe, a partir da aprendizagem obtida por meio da experiência realizada na Escola Classe 49, perspectivas futuras de contribuir com outras instituições de ensino que venham a possuir questões no trabalho de desenvolvimento das práticas de compreensão leitora dos alunos.

Como pedagoga pude refletir que a construção deste trabalho se deu de forma enriquecedora e realista, pois o estudo concluído acerca das dificuldades de compreensão leitora de alunos do ensino fundamental é um exemplo de que é preciso refletir sobre as práticas que norteiam o trabalho com a leitura em sala de aula e sobre como há possibilidades de mudanças no âmbito da interpretação de textos, livros, filmes, etc.

Nós professores devemos optar pela constante busca do conhecimento, sendo este o principal ensinamento que levo para o meu futuro a partir desta experiência. A formação continuada deve ser priorizada pelos profissionais da educação e refletida dentro e fora do contexto de uma sala de aula.

Acredito que como enriquecimento pessoal e profissional, este trabalho veio ampliar e instigar a necessidade de especializar o conhecimento sobre o letramento de crianças numa eventual pós-graduação ou mestrado na Universidade de Brasília, bem como melhor analisar os alunos em sala de aula, conhecendo os diferentes perfis e as peculiaridades de cada um, para assim dar início a um trabalho pedagógico eficaz e coeso, que deve, ou deveria, ser o objetivo de todo educador. 


\section{REFERÊNCIAS BIBLIOGRÁFICAS}

ANDRÉ, Marly Eliza D.A. de. Etnografia da prática escolar. 13. ed. Campinas, SP: Papirus, 1995. (Série Prática Pedagógica).

BORTONE, Márcia Elizabeth. A construção da leitura 1. Brasília: Centro de Formação Continuada de Professores da Universidade de Brasília- CFORM/UnB: Secretaria de Educação Básica - MEC/SEB, 2004.

BORTONI-RICARDO, Stella Maris. Educação em língua materna. A sociolinguística na sala de aula. Parábola Editorial, 2006.

BORTONI-RICARDO, Stella Maris. O professor pesquisador: Introdução à pesquisa qualitativa. São Paulo: Parábola Editorial, 2008.

http://www.interfilmes.com/filme 16453 Ratatouille-\%28Ratatouille\%29.html Acesso em: 10 nov. 10.

http://www.sulear.com.br/texto06.pdf Acesso em: 10 nov. 10.

http://www.ebooksbrasil.org/eLibris/vigo.html\#ind10 Acesso em: 10 nov. 10

KLEIMAN, Ângela B. Os significados do letramento: Uma nova perspectiva sobre a prática social da escrita. Campinas, SP: Mercado de Letras, 1995.

KLEIMAN, Ângela B.; MORAES, Silvia E. Leitura e interdisciplinaridade: Tecendo redes nos projetos da escola. Campinas: Mercado das Letras, 1999.

MARTINS JUNIOR, Joaquim. Como escrever trabalhos de conclusão de curso. Petrópolis, RJ: Vozes, 2008.

SOARES, Magda. Letramento: Um tema em três gêneros. 2. ed. Belo Horizonte: Autêntica, 2004.

VYGOTSKY, Lev Semenovich. A formação social da mente. O desenvolvimento dos processos psicológicos superiores. 6. ed. 1998. 
ANEXO A

\section{REPRESENTAÇÃO DAS CRIANÇAS REFERENTE AO TEMA APRESENTADO EM SALA DE AULA: A UNIÃO}


ANEXO B

\section{REPRESENTAÇÃO DAS CRIANÇAS REFERENTE AO TEMA APRESENTADO EM SALA DE AULA: FILME RATATOUILLE}


ANEXO C

MÚSICA UTILIZADA EM SALA DE AULA: "A TARTARUGA AMIGUINHA" 
ANEXO D

\section{FICHA DO PROJETO 4 COM RELAÇÃO DE PARTICIPAÇÕES E INTERVENÇÕES EM AULA}

